\title{
Never a lost art: Theco-peritoneal shunting in IIH
}

\author{
Ayush Dubey*, Sunil Athale and Mukesh Dube \\ Department of Neurology, SAIMS Medical College and PGI, Indore (MP), India
}

Idiopathic Intracranial Hypertension (IIH) is a disorder mostly affecting obese women of child bearing age [1]. Previously known as pseudotumor cerebri, it is a syndrome in which intracranial pressure is elevated with normal Cerebrospinal Fluid (CSF) composition and no evidence of hydrocephalus or mass lesion. Diagnosis is based on Modified Dandy's Criteria after ruling out other causes of raised intracranial pressure including drug intake, hypothyroidism or other structural lesions including cerebral venous thrombosis. The most common symptoms of IIH are headaches, occurring in around $90 \%$ of cases and visual disturbances including transient visual obscurations and diplopia. Typical signs include papilledema, associated initially with enlarged blind spots, followed by arcuate visual field defects when there is progression [2]. Management approaches include medical treatment in the form of acetazolamide or surgical options which include repeated lumbar punctures, traditional theco-peritoneal(T-P) shunting, optic nerve sheath fenestration, ventriculo-peritoneal (V-P) shunting or subtemporal decompression.

We describe a case of a twenty-year-old female of post-partum period and with BMI (Body Mass Index) of $38.22 \mathrm{~kg} / \mathrm{m}^{2}$ who presented with history of generalized dull aching headache of 15 days duration with rapidly deteriorating vision since 10 days. Examination showed grade 5 papilloedema with bilateral lateral rectus palsy. She had only perception of light left in both the eyes on ophthalmological examination. Her investigations of interest showed normal serum TSH (1.65) with normal MRI brain and venogram. Her CSF opening pressure was $58 \mathrm{~cm}$ with normal chemical composition. She was started on acetazolamide but seeing the fulminant course of IIH in this case,decision for theco-peritoneal shunting was taken. Patient improved significantly after the procedure and attained a normal visual field after 2 months and is doing well since last two years with no headache or visual symptoms.

Theco-peritoneal shunt has traditionally been the method of choice in IIH. It is a very effective procedure to treat this condition when conservative treatment fails and the vision is threatened. The efficacy of T-P shunting is maintained as long as the shunt remains patent $[3,4]$. The technique is safe, less time-consuming, and more suitable for morbid obese patients with high body fat percentages as well as those patients who are pregnant [1]. Despite of newer modalities like optic nerve sheath fenestration, T-P shunting still holds its position firm as a reliable treatment option. Although both these procedures have shown variable and almost comparable results in some studies, the decision for which surgical procedure is best in IIH remains surgeon and institution dependent based upon the local surgical expertise and availability [5]. Prospective, randomized, controlled trials are needed for head to head comparison of these modalities.

\section{References}

1. Badve M, McConnell M, Shah T, Ondecko-Ligda K, Poutous G, et al. (2011) Idiopathic intracranial hypertension in pregnancy treated with serial lumbar punctures. Int $J$ Clin Med 2: 9-12.

2. Friedman DI, Jacobson DM (2002) Diagnostic criteria for idiopathic intracranial hypertension. Neurology 59: 1492-1495. [Crossref]

3. Binder DK, Horton HC, Lawton MT, McDermott MW (2004) Idiopathic intracranial hypertension. Neurosurgery 538-552.

4. Burgett RA, Purvin VA, Kawasaki A (1997) Lumboperitoneal shunting for pseudotumor cerebri. Neurology 49: 734-739. [Crossref]

5. Spitze A, Lam P, Zubidi N, Yalamanchili S, Lee A (2014) Controversies: Optic nerve sheath fenestration versus shunt placement for the treatment of idiopathic intracranial hypertension. Indian J Ophthalmol 62: 1015-1021. [Crossref]
Copyright: (C2017 Dubey A. This is an open-access article distributed under the terms of the Creative Commons Attribution License, which permits unrestricted use, distribution, and reproduction in any medium, provided the original author and source are credited.
Correspondence to: Ayush Dubey, E-29, 45 Bungalows, T T Nagar, Bhopal(MP), India

Key words: Theco-peritoneal shunting, Idiopathic Intracranial Hypertension

Received: October 04, 2017; Accepted: November 03, 2017; Published: November 06,2017 